\title{
DISTRICT NURSING IN ENGLAND AND WALES BEFORE THE NATIONAL HEALTH SERVICE: THE NEGLECTED EVIDENCE
}

by

\author{
ENID FOX *
}

In Britain, the nurse provided by the National Health Service to attend patients in their homes is always the "district nurse", despite other and later descriptions of her work as "home" or "community" nursing.' The popular usage not only betrays district nursing's philanthropic origins as a service organized on the district basis typical of Victorian visiting charities, ${ }^{2}$ but also testifies to the district nurse's ubiquity well before the state paid her wages in 1948, when home nursing became one of the responsibilities assigned to local authorities as part of the National Health Service. ${ }^{3}$ She was sufficiently enshrined in popular consciousness for audiences to appreciate the scene in Dodie Smith's Dear octopus, first produced in 1938, where children dispute the merits of "District Nurse" as a more powerful expletive than "Damn Blast Devil Hell and Strike me Pink". ${ }^{4}$ The film version of A. J. Cronin's The citadel, released in the same year, includes a vignette of a district nurse as a well-established local character. ${ }^{5}$

The particular interest of district nursing's history before 1948 lies in its character as a voluntary service. It was voluntary in the sense of being funded and controlled by private initiative rather than by statutory provision, yet was important enough to be incorporated in the National Health Service although it had hitherto received very little from public funds.

* Enid Fox, PhD, Principal Lecturer in Social Policy, School of Health and Human Sciences, University of Hertfordshire, College Lane, Hatfield, Herts., AL10 9AB.

Sources for this paper include archives made available by the Queen`s Nursing Institute (formerly the Queen`s Institute of District Nursing), with permission for citations. The help of past and present staff of the Institute is gratefully acknowledged, as is the advice of Martin Powell, University of Hertfordshire, on an early draft of the paper.

Abbreviations used are PRO: Public Record Office; QIAR: Queen`s Institute’s Anmual reports; QICM: minutes of the Council of the Queen's Institute.

\footnotetext{
1 "Home nursing" was the term used in the National Health Service Bill, 1946: see Charles Webster, The health services since the "1ar, vol. 1, London, HMSO, 1988, p. 96; "community nursing" is a later usage, e.g., in the Report of the Royal Commission on the National Health Service, HMSO, Cmnd 7615, 1979, para. 7.22.

- See F. K. Prochaska, Women and philanthropy in nineteenth-century England, Oxford University Press, 1980, ch. 4 , for district visiting.

${ }^{3}$ The National Health Service Act, 1946, s. 25, placed on local authorities the duty of providing a home nursing service, either by direct employment or voluntary agency. The duty was transferred to District Health Authorities when the NHS was reorganized in 1974.

${ }^{+}$Dodie Smith, Dear octopus, London, Samuel French, 1938, p. 41.

${ }^{5}$ See Roger Manvell, Film, Harmondsworth, Penguin, 1946 (1st ed. 1944), pp. 131, 236, for the dating of the film of The citcidel.
} 


\section{Enid Fox}

The two inter-war decades, 1918-1939, were notable for the development of public health and welfare services to the accompaniment of a chorus of concern that they would erode the charitable impulse to the detriment of the social good. ${ }^{6}$ The voluntary sector's monopoly of district nursing is therefore especially worthy of research, but the subject has been generally neglected. In their textbook on nursing history, Robert Dingwall, Anne Marie Rafferty and Charles Webster relate the paucity of published sources to district nursing's "invisibility in policy debate" and the consequent absence of evidence in major and official archives. ${ }^{7}$ As they point out, the voluntary "district nursing associations" that employed district nurses before 1948 were local in character, and their surviving records are scattered. Dingwall et al. identify only two published histories, useful but limited. ${ }^{8}$ They are commemorative works published in 1960 and 1987, commissioned by the organization that is now the Queen's Nursing Institute: colloquially, the "Queen's Institute”. The Institute promoted and co-ordinated a form of district nursing with two grades of nurses. Its historians have concentrated on the higher-grade "Queen's nurses", and offer no quantified data whereby to assess the relative strengths of the two nursing grades in the work-force, the significance of the Institute's system in relation to other district nursing, or the national availability of the service. The absence of such information not only inhibits judgement about how much and what sort of home nursing was available, but also about the voluntary sector's capacity to provide an adequate service and the extent to which the Queen's Institute represented the district nursing movement at large.

In fact, there is no lack of quantification, although historians have so far not exploited it. District nursing was covered in the major report on British health services published in 1937 by the independent research agency P.E.P. (Political and Economic Planning). ${ }^{9}$ Its brief but broadly reliable account estimated there to be about 8,000 district nurses in Great Britain in the mid-1930s, supported to no less than 40 per cent of their costs, and possibly much more, by the populations they served: ordinary people raised at least half a million pounds a year to keep district nursing going. ${ }^{10}$ That the report's anonymous authors described the service as "little advertised" may say more for the social circles from which P.E.P. drew its research working-parties than for the general public who helped to pay for their district nurses because they could not afford private home nursing.

The basis for P.E.P.'s estimate was a national survey of district nursing that was conducted and published by the Queen's Institute in 1935. " Another contemporary publication that drew on it was Constance Braithwaite's account of the role of voluntarism

\footnotetext{
${ }^{6}$ Nora Milnes, 'The position of voluntary social services in 1918', in Henry A. Mess, et al. (ed. Gertrude Williams), Voluntary social services since 1918, London, Kegan Paul, Trench, Trubner, 1947, pp. 8-27. Examples are J. C. Pringle, British social services: the nation's appeal to the housewife and her response, London, Longmans, 1933; L. H. Bell, 'The respective spheres of the state and of voluntary organizations in the prevention and relief of poverty in London at the present day', MA thesis, University of London, 1935; Constance Braithwaite, The voluntary citizen, London, Methuen, 1938.

${ }^{7}$ Robert Dingwall, Anne Marie Rafferty and Charles Webster, An introduction to the social history of nursing, London, Routledge, 1988, p. 173.

${ }^{8}$ Ibid.; Mary Stocks, $A$ hundred years of district nursing, London, George Allen and Unwin, 1960; Monica E. Baly, A history of the Queen's Nursing Institute, London, Croom Helm, 1987.

${ }^{9}$ P.E.P., Report on the British health services, London, P.E.P., 1937, pp. 174-80.

10 Ibid., p. 177. The proportion clearly identified as from user sources was acknowledged to be understated: see Braithwaite, op. cit., note 6 above, p. 297.

"Queen's Institute of District Nursing, Survey of district nursing in England and Wales, London, Queen's Institute, 1935.
} 
in relation to state welfare, which is supported by case studies of district nursing in different types of area. ${ }^{12}$ Braithwaite expounded a philosophy of welfare that derived from democratic socialism, and produced the axiom that the state should provide essential services and indicated criteria for identifying them. On the strict application of her principles, the conclusion that local authorities should provide district nursing was inescapable, yet she resisted it. Her reasoning was pragmatic: she weighed the theoretical advantages of a statutory service against the voluntary sector's proven ability, arguing that the Queen's Institute had achieved a level of national provision and co-ordination unlikely to be matched by local authorities. She concluded that, in the case of district nursing, the principle of state responsibility would be best met by local authorities' being given the duty of ensuring adequate home nursing but fulfilling it by supporting the voluntary agencies and making direct provision only where voluntarism failed. ${ }^{13}$

The politics of voluntarism will be further, if briefly, discussed later in this paper. Its central objective is to present and discuss the evidence of the Queen's Institute's survey, explaining how it was used and establishing its importance. It is first of all necessary to provide a note on the Institute and its system: this is covered in the section that follows. Six further sections deal with various aspects of the survey, including its context and provenance, its findings on the breadth and depth of district nursing's territorial coverage, its reception at the Ministry of Health, and its financial findings and implications. The paper concludes with a summary account of district nursing's subsequent fortunes, with observations on what its history suggests about the limits of voluntarism.

\section{THE QUEEN'S INSTITUTE AND ITS SYSTEM OF DISTRICT NURSING}

The Queen Victoria's Jubilee Institute for Nurses, later the Queen's Institute for District Nursing and now the Queen's Nursing Institute, was founded in 1887 to provide home nursing for the sick poor. It did not employ nurses directly, but operated a national system of affiliation, training and inspection to promote and standardize district nursing on a model that had been developing for thirty years or so before its foundation. ${ }^{14}$

District nursing associations affiliated to the Institute were assured of the supply of "Queen's nurses", fully-trained hospital nurses with further training in district work, for employment on terms prescribed by the Institute. The associations retained their constitutional autonomy but observed conditions that required them normally to employ only Queen's nurses as district nurses, to conform to certain administrative requirements, and to accept regular visits from the Institute's inspectors. The Institute recognized that these arrangements were inappropriate to many rural districts, but special terms of affiliation that allowed for the rural employment of nurses whose training was not of the standard required for Queen's nurses were unsuccessful until the Institute introduced "county affiliation" in 1897. It was available to "County Nursing Associations" which promoted and co-ordinated small rural associations; the small associations employed qualified midwives, with elementary training in home nursing, as "village nursemidwives", on locally negotiated terms.

\footnotetext{
${ }^{12}$ Braithwaite, op. cit., note 6 above.

1.3 Ibid., p. 323.

${ }^{1+}$ Baly, op. cit., note 8 above, pp. 6-32.
} 


\section{Enid Fox}

The Institute sympathized with the movement for trained and licensed midwifery that culminated in the Midwives Act of 1902, and, although it did not allow Queen's nurses to practise midwifery in towns, it had always accepted their employment as nurse-midwives in rural districts too small to justify either full-time nurses or the trained independent midwives whose practice was promoted by the midwifery reformers. ${ }^{15}$ The Institute arranged midwifery training for enough Queen's nurses to meet its rural affiliates' demands, but some rural districts could not raise enough money for them, even allowing for the midwifery fees that nurse-midwifery brought in. ${ }^{16}$ The special terms that were originally devised called for nurses with some hospital training, also too expensive for many rural districts, but county affiliation could meet their needs. Its most important condition was the employment of an experienced Queen's nurse as County Superintendent, to supervise the village nurse-midwives' work.

Once county affiliation was in place, the Queen's Institute's system was theoretically capable of sustaining a national service of district nursing, entailing two nursing grades but standardized in the sense that the expectations of the lower grade were set and monitored by reference to Queen's nurses' standards. The extent to which national standardization was to be achieved depended on district nursing's popularity as a philanthropic and voluntary enterprise, and on associations' propensities to affiliate. Without evidence on these matters, it is difficult to assess the value of accounts of the Queen's Institute and the nursing done in its connection, or the significance of the ample statistical data in the Institute's Annual reports. Such evidence became available when the Institute's national survey was published in 1935.

SURVEY OF DISTRICT NURSING IN ENGLAND AND WALES, 1935: CONTEXT, PROVENANCE AND POLITICS

The Survey's especial value is its inclusion of associations that were not affiliated to the Institute; it acknowledges their co-operation in supplying data. ${ }^{17}$ It establishes the Institute's national dominance, showing that by 1935 most district nursing was done in the Institute's connection. It stands as a guide for assessing the Institute's position before and after 1934-5, even though it was conducted for one year only and was not repeated. The Institute's Annual reports were published, and were customarily reviewed in the professional press; they provide evidence on affiliations, the numbers and types of nurses, and the work that they did. They support the view that the Institute was district nursing's premier agency, but include nothing to show what that meant in relation to unaffiliated nursing. Considered alongside the Survey, they suggest that the relativities which it demonstrated were more or less representative of the whole inter-war period. The Institute expanded its empire as new associations were formed and older ones decided against continued independence, but the associations connected to it by the end of the First World

\footnotetext{
15 Ibid., p 30; the Queen's Institute's terms of affiliation, 7 and 8. See also Dingwall et al., op. cit., note 7 above, pp. 154-8, on the movement for midwifery reform.

${ }^{16}$ Enid Fox, "An honourable calling or a despised occupation: licensed midwifery and its relationship to district nursing in England and Wales before 1948', Soc. Hist. Med., 1993, 2: 237-59, p. 241.

${ }^{17}$ Queen's Institute of District Nursing, op. cit., note 11 above, pp. 3, 6.
} 


\section{District nursing in England and Wales}

War must have represented something not far short of the three-quarters or so of the country's district nursing over which it claimed surveillance in $1935 .^{18}$

This rough estimate indicates why the Survey is a key document for the student of domiciliary health services before 1948 , not only because of its empirical data, but also because of its value in enabling judgements to be made about the representativeness of district nursing done in connection with the Queen's Institute, and of information emanating from the Institute. The Survey's evidence is further discussed later in this paper, but there is some profit in first considering its provenance, and it needs to be placed in the context of the prospects for the voluntary sector's district nursing in the early 1930s. The Institute's Annual reports for England and Wales show 5,733 nurses, nurse-midwives, midwives, trainees and others working under its auspices in 1930, more than three times as many as when totals were reported for the first time in 1906, and there was a steady upward trend. $^{19}$

The increase in numbers from the early 1900 s had been consistently better in rural than in urban areas. From the end of the First World War, more village nurse-midwives were employed than Queen's nurses, although there was always a small but unidentified minority of Queen's nurses in rural posts. The success in county areas depended very much on the rural associations' midwifery, for which charges were made and which had been eligible for discretionary grants from public funds since $1916 .{ }^{20}$ Almost all County Councils supported midwifery as part of the maternity and child welfare services that became more widespread with the implementation of the Maternity and Child Welfare Act of 1918. Another feature of rural associations was their customary use of "provident" funding: residents contributed small regular payments, often a penny a week, towards the cost of the nurse. ${ }^{21}$ The Queen's Institute encouraged users' financial support, but, until the 1930s, provident schemes were deemed generally unsuitable for towns, mostly for administrative reasons to do with maintaining collections and managing membership. If urban users paid anything in addition to contributing to the charitable efforts that were customary in both town and country, it was usually by way of small charges or voluntary donations in consideration of services rendered. Such practices were less productive than schemes for regular contributions. Apart from anything else, illness or accidents might rule out all possibility of payments from patients who could have paid small regular amounts when in normal health.

By 1930 it was clear that if district nursing was to maintain its position and continue to expand, it had to increase the proportion of funds that came from sources other than philanthropy. There were two that might be tapped: users who did not yet contribute, and public authorities. The Queen's Institute's Annual reports from 1929 onwards show how it

\footnotetext{
${ }^{18}$ Enid Fox, 'District nursing and the work of district nursing associations in England and Wales, 1900-48', PhD thesis, University of London, 1993, p. 158. Rough estimates suggest that between the wars the population covered by associations connected to the Institute rose from about 47 to 76 per cent of the total population. There is no firm basis for estimating how far the total population was covered by all district nursing, including that of unaffiliated associations, at the beginning of the period, but it is unlikely to have exceeded 70 per cent.

19) Ibid., pp. 58-9.

20 Ibid., pp. 159-60. The Local Government Board's circular of 29 September 1916 specified that local authorities were empowered to pay for or towards midwifery for necessitous women, and offered aid towards local authorities' and voluntary agencies' costs of providing midwives in areas that would otherwise have had none.

${ }^{21}$ Ibid, pp. 118-25, 244-50.
} 


\section{Enid Fox}

first commended and later promoted a new, workplace-based form of provident funding, pioneered in Leicester, that often proved practicable in places where contributory schemes on the rural lines were not feasible. ${ }^{22}$ The Survey was one outcome of the Institute's deliberations about seeking support from public funds.

Local authorities had no powers to employ district nurses, or to support district nursing associations' general work until the Public Health Act of 1936 enabled them to do so. ${ }^{23}$ But since before the Institute's foundation, the Poor Law authorities had been able to make grants towards home attendance for patients on poor relief, and local authorities' powers covered work other than general home nursing that district nurses might do. As well as the midwifery that was especially likely in rural areas, such work included school nursing, attendance in cases of certain infectious diseases, and rural health visiting. ${ }^{24}$ The Institute had consistently pressed for local authorities to enlist district nurses' co-operation, but before 1935 it had no policy on the question of new statutory powers.

Statutory powers took on a new prominence in the Institute's proceedings after the Local Government Act of 1929. Local authorities then reviewed their health services in the light of a new system-“block grants"-for determining central government's contribution to local services, and the Poor Law powers were transferred to them. The Institute's Council noted with satisfaction that the block grants looked likely to be favourable to district nursing, and its minutes for February 1932 record a request for the County Councils Association's help in securing local authorities' maximum use of district nurses' services in connection with the Poor Law. ${ }^{25}$ This was about the time when the Institute was stepping-up its encouragement of new provident schemes, but one recently appointed member of its Council had reservations about their feasibility in depressed areas. Lady Williams, of the National Birthday Trust, founded in 1928 to promote maternal and infant welfare, was pessimistic about a special effort that was put in hand to develop provident funding in Glamorgan, where the Trust had an experimental project. ${ }^{26}$ When she voiced her doubts about the prospects for provident funding in such places, Lady Williams proposed a national survey to identify further needs for district nursing.

The proposal was uncontroversially accepted, but it was not Lady Williams's only initiative. There was general concern when the Institute's Council's meeting of July 1934 heard that Sir Gerald Hurst's Private Member's Bill on domiciliary health services had just passed its first reading in the House of Commons; Lady Williams owned to having instigated it. ${ }^{27}$ It included powers for local authorities to employ district nurses and to support nursing associations' general home nursing. The reason for the Council's displeasure was its members' resistance to statutory intervention in what they believed

22 QIAR, 1929-37.

${ }^{23}$ Public Health Act 1936, section 178: "A county council or local authority may contribute by way of an annual subscription towards the support and maintenance of any association for providing nursing."

24 The Ministry of Health did not accept district nurses' health visiting as part of urban services qualifying for grants from central government under the Maternity and Child Welfare Act of 1918. (See Fox, op. cit., note 18 above, pp. 164-5.)

${ }^{25}$ QICM, 1 I July 1928: the new system "recognise|d| the principle of providing nursing and midwifery in the homes of the people by voluntary agencies", and enabled grants to be awarded on a five-year basis; QICM, 24 February 1932: letter to the County Councils Association.

${ }^{26}$ QICM, 28 February 1934; PRO, PRO 30/63/559, papers on Glamorgan County Nursing Association: report on a meeting of the National Birthday Trust and the Queen's Institute, on the Rhondda Valley, 2 March 1934.

27 QICM, 11 July 1934. 
should be an exclusively voluntary enterprise. There were no objections to the Institute's established policy of seeking the fullest use of all existing powers, under which support for general nursing was limited to attendance on "Poor Law patients", but unlimited powers that included direct employment were threatening. They implied not only that local authorities might compete with the nursing associations, but that new funds might be offered as payments for work done on the local authorities' behalf-contracted-outrather than as grants towards the associations' own work. Such terms would mean that the associations would become agents of local authorities, and agency relationships might entail unwelcome official control. As it turned out, the Domiciliary Services Bill failed at its third reading, even though its sponsor accepted amendments that limited its powers to the types of grants that became possible two years later, under the new Public Health Act.

Lady Williams had no support from her fellow-members of the Queen's Institute's Council on the question of statutory powers as wide as Sir Gerald Hurst's unamended Bill proposed, but powers that did not include the direct provision of home nursing were a different matter. Civil servants at the Ministry of Health attributed the Bill's failure to lobbying by the Queen's Institute, ${ }^{28}$ but according to the Institute the reason was the County Councils Association's successful promotion of the argument that a proposal tantamount to a national service of district nursing was proper only to a Government Bill after a full inquiry; it was too important for a Private Member's Bill. ${ }^{29}$ It is, however, difficult to see how the argument about a national service could have been sustained after the Bill's amendment. Within a year of the Bill's failure, the Survey was the basis for a meeting between officials of the Ministry of Health and a deputation from the Institute, who sought new powers for local authorities to aid nursing associations' general work and explained that the Institute had objected to Sir Gerald Hurst's Bill only in its unamended form. ${ }^{30}$ The County Councils Association was one of the bodies that asked for the Public Health Bill of 1936 to include new powers of support for home nursing. ${ }^{31}$

There was in fact a division of opinion on the Institute's Council. Its County Nursing Association Committee (in effect, its rural representation) recorded dissent from the policy of seeking new powers some months after the deputation to the Ministry. ${ }^{32}$ The logic of the split is understandable in the light of the Survey, which can be interpreted as showing that rural areas were so well covered by 1935 that there were reasonable prospects for full coverage with no further legislation. The political complexities of the collaborations between County Councils and County Nursing Associations deserve further study; they relate to grants that were merely supportive, as for midwifery until $1936,{ }^{33}$ or were payments for work that was contracted-out. District nurses' agency for domiciliary public health services and school nursing was especially likely in rural areas. Both types of funding might entail official intervention that was undesirable from the nursing

\footnotetext{
${ }^{28}$ PRO, MH 55/759, Ministry of Health's departmental comments on the Survey, sent to the Minister by the President of the Queen's Institute on 25 October 1935.

2" QICM, 5 December 1934: the outcome of the Domiciliary Services Bill.

${ }^{30}$ PRO, MH 55/759: notes on the deputation to the Ministry of Health, 20 November 1935.

${ }^{31}$ PRO, HLG 29/227, papers on the Public Health Bill, 1936: undated submission from the County Councils Association; see also the Urban District Councils Association`s similar submission, 28 February 1936.

32 QICM, 4 March 1936.

${ }^{3.3}$ The Midwives Act of 1936 required local authorities to provide full services of salaried, domiciliary midwives and encouraged the used of voluntary agencies. (See Fox, op. cit., note 16 above, pp. 239, 241-2, 248-51.)
} 


\section{Enid Fox}

associations' point of view, but they might also mean leakages of public funds to the general home nursing that should not, strictly speaking, attract them. Public health and school nursing were usually only very small parts of rural nurses' work, with little involvement by public officials. Statutory intervention in district nursing would have been a very different matter, and avoiding it was likely to have higher priority than the chance of a little more money. As to the possibility that current arrangements sometimes included a hidden subsidy towards district nursing, a few County Nursing Associations may have seen their financial interests as most prudently served by leaving things be. There was definitely a certain community of interest between County Councils and County Nursing Associations, with some of the county associations enjoying notably good relationships with their County Councils' health committees and officers, and county councillors sometimes serving on county associations' committees; the two explanations of the fate of Sir Gerald Hurst's Bill probably conceal lobbying by successful alliances. The Queen's Institute's later representations to the Ministry, made without reference to the views of its County Nursing Association Committee, suggest that its Council's decision-making was less than democratic.

The evidence from the Survey shows how urban needs may have led the Institute to proceed with a policy that its rural representatives did not endorse.

\section{THE SURVEY: DATA AND SOURCES}

The Survey was based mainly on data for 1934. It covered the numbers and locations of nurses, the populations they served, the needs for more nurses, and associations' finances. ${ }^{34}$ This paper does not attempt a full analysis, but indicates the broad picture presented by the Survey, and its historical significance. A summary judgement, amplified in the next four sections, is that the Survey is reliable on the numbers of nurses and breadth of coverage, is questionable on the depth of coverage and of further needs, and is useful but limited on finance.

The basic statistical data are of the type that the Queen's Institute routinely collected from its affiliates and published in its Annual reports, but the data as presented in the Survey are not directly comparable to the series in the Reports. The Reports' totals include "midwives, trainees and others"; the numbers of Queen's nurses and village nursemidwives are separately identifiable, but it is not possible to disaggregate the rest. The Survey's totals of nurses allow for trainees' work and, by implication, for that of "others". There were always some nurses who were not in the two standard grades but whose employment was allowed for some exceptional reason-say, as temporary or relief nurses.

The Survey reported good co-operation from unaffiliated associations, and it is unlikely that any were overlooked, given the Institute's national network of affiliates and inspectors. The Survey's only reservations were about Greater London, and were to do with identifying the precise populations served by the associations. The problems were attributed to population movements, discrepancies between the London associations' boundaries and those of the metropolitan boroughs, and the lack of a County Nursing Association for Middlesex. Out of the 62 administrative counties in England and Wales,

\footnotetext{
${ }^{34}$ Queen's Institute of District Nursing, op. cit., note 11 above. The Survey's 27 pages are mostly tables; specific citations are not provided for subsequent references to their data.
} 


\section{District nursing in England and Wales}

60 had County Nursing Associations, 10 of which were unaffiliated. The Survey's reference to directly affiliated urban associations as providing nurses in "one hundred and thirty-five Cities and Towns" understates the number of associations, as some such places had more than one.

THE SURVEY: BREADTH OF DISTRICT NURSING'S COVERAGE

The Survey's tables present the numbers of nurses working with affiliated and unaffiliated associations by reference to administrative areas: counties, county boroughs, and London's metropolitan boroughs. The nurses' qualifications are not stated, but the preamble to the tables explains the Institute's system and includes figures for the year to 31 December 1934: 2,361 Queen's nurses, 2,853 village nurse-midwives. (Trainees, midwives and others are not included in these figures.) The grand total of nurses identified for the Survey was 7,170; 6,228 (86 per cent) worked in the Institute's connection. Table 1 shows the breakdown in terms of types of administrative areas.

Table I

District nurses in England and Wales, 1934-5

\begin{tabular}{|c|c|c|c|c|}
\hline & & Affil. (a) & Unaffil. (b) & Population, in $1,000 \mathrm{~s}$ (c) \\
\hline English counties & & 4,576 & 558 & 20,115 \\
\hline English county boroughs & & 920 & 228 & 12,767 \\
\hline Welsh counties & & 484 & 21 & 2,045 \\
\hline Welsh county boroughs & & 48 & - & 548 \\
\hline London boroughs & & 200 & 135 & 4,389 \\
\hline & Totals & 6,228 & 942 & 39,864 \\
\hline
\end{tabular}

Notes: (a) nurses with affiliated associations; (b) nurses with unaffiliated associations; (c) from the census of population, 1931.

Only 5 per cent of the population (4 per cent for England, 13 per cent for Wales) had no nursing associations. Of the "nursed" 95 per cent, 75 per cent were accounted for by associations connected to the Institute and 20 per cent by others. The difference between these proportions and the percentages of nurses working in connection with the two types of associations ( 86 per cent and 14 per cent) is due to allowances made for factors that depressed some nurses' case-loads of general home nursing, and which were reflected in the Survey's estimates of needs.

\section{THE SURVEY: DEPTH OF DISTRICT NURSING'S COVERAGE}

The Survey estimated the adequacy of nursing services on the basis of one nurse to a population of 7,000-9,000, for general nursing only. The population figure was reduced to $5,000-6,000$ for combined nurse-midwifery, and to 3,000 where the nurse undertook public health work for a local authority. The variations were most likely to apply in the rural districts covered by county affiliation-hence the disparity between the proportion of nurses under the Institute's tutelage and its "market share". The three-part formula informed the Survey's estimates of further needs, but does not account for all variations from the basic measure. The estimates also allowed for the character of districtsscattered populations and hilly terrain were mentioned, as well as unspecified special 


\section{Enid Fox}

circumstances - and the judgements that were applied in the estimating are not detailed in the Survey. The arithmetical variations, unadjusted, are very crude; for example, "public health work" might have meant acting as a County Council's agent for all of its domiciliary and school services or for only one small part of them.

The Survey's estimates of needs are presented area by area, categorizing the county areas covered by affiliated associations by reference to the three groups created by the formula. The Survey noted that the average population per nurse varied considerably within each of the three groups, as illustrated in Table 2.

Table 2

Populations per nurse in English and Welsh counties, 1934-5

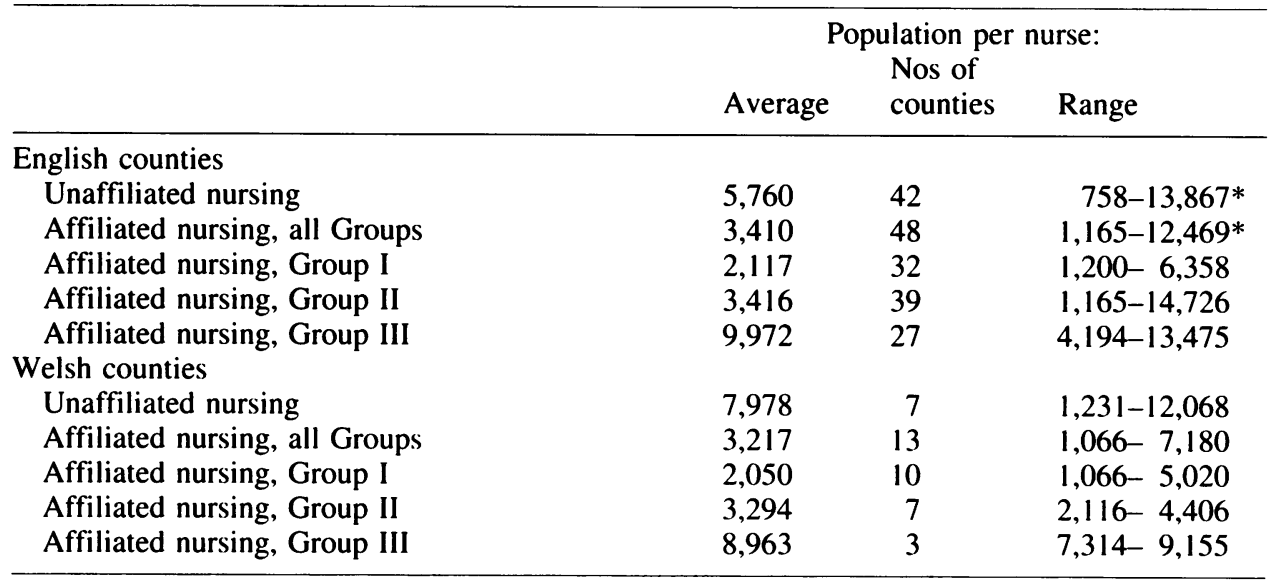

Notes: Group I, general nursing, midwifery and public health work; Group II, general nursing and midwifery; Group III general nursing only.

*These upper extremes are for Middlesex, with affiliated associations but no County Nursing Association. The next highest figure for affiliated nursing in this category was 7,534 , for Lancashire.

The ranges in Table 2 reflect some isolated examples of very small associations and of nurses nominally covering very large areas; the case of Middlesex is the most extreme. The table represents a "nursed" population of 20,543,724; approximately 98 per cent of the total "county" population and 52 per cent of that for England and Wales. The approximate percentages for the different types of services are as follows: unaffiliated, 16 per cent; Group I, 28 per cent; Group II, 30 per cent; Group III, 26 per cent. The Survey estimated that a complete service of district nursing required 1,625 more nurses, as shown in Table 3.

As has been explained, the Queen's Institute used the Survey to support its argument that local authorities should have new statutory powers, against the wishes of its Council's rural representation. On the figures presented in Table 3, it is understandable why County Nursing Associations, at least in England, may have preferred doing without extra support to risking official interference with their nursing. The finances of the Welsh County Nursing Associations, discussed later in this paper, help to explain why their representatives may have agreed with their English counterparts, despite the greater needs for more nurses in Wales. 
District nursing in England and Wales

Table 3

Estimated needs for more district nurses, 1935 (England and Wales)

\begin{tabular}{|c|c|c|}
\hline & Nurses needed & Percentage of existing provision \\
\hline English counties & 739 & 14 per cent \\
\hline English county boroughs & 548 & 48 per cent \\
\hline Welsh counties & 106 & 21 per cent \\
\hline Welsh county boroughs & 21 & 44 per cent \\
\hline \multirow{2}{*}{ London boroughs } & 211 & 63 per cent \\
\hline & 1,625 & 23 per cent \\
\hline
\end{tabular}

Note: The 7,170 nurses identified in 1935 represented 81.5 per cent of the estimated needs for a full service of 8,795 nurses.

The correspondence between the high proportion of village nurse-midwives in the Queen's Institute's system and the relatively good rural coverage cannot have escaped attention when the Survey was publicized. It suggested that there were greater difficulties about matching needs to nurses where the posts required fully-qualified nurses, and could have undermined the Institute's image of district nursing as personified in the Queen's nurse. But there are no signs in the records of the Institute's dealings with the Ministry of Health on the Survey that the evidence of the Institute's reliance on village nursemidwifery in achieving near-national coverage was an embarrassment. ${ }^{35}$ Readers of the Institute's Annual reports would have known of the composition of the work-force, and that the rate of increase in the lower grade was slackening off whilst that of the Queen's nurses was rising. Some factors that made for smaller case-loads in rural districts than in towns, possibly very much smaller, were self-evident, whether or not the Survey, accurately reflected them in its estimates of needs. The composition of the work-force in the 1930s was no hindrance to the Institute's promotion of its case for new statutory powers. Something else that the Survey revealed, which might have made for difficulties in promoting the case and safeguarding voluntary control, was the uneven distribution of the estimates of unmet need. These were the aspects of the Survey that attracted most attention at the Ministry of Health.

\section{DISTRICT NURSING, THE SURVEY, AND THE MINISTRY OF HEALTH}

Any difficulties implied by the estimates remained "might-have-beens" because the possibility of bringing district nursing up to an adequate level was never on the political agenda until planning began in 1944 for a National Health Service envisaged as including all domiciliary health care. ${ }^{36}$ The atmosphere at the Ministry of Health in 1935 was sympathetic, and the Parliamentary case for the new powers of support that soon followed was that they would merely put home nursing on the same footing as public hospitals, which for some years had not been restricted to Poor Law patients. ${ }^{37}$ But the Ministry did

${ }^{35}$ PRO, MH 55/759, op. cit., notes 28 and 30 above.

${ }^{36}$ Ministry of Health and Department of Health for Scotland, $A$ national health service, Cmd 6502, London, HMSO, 1944 (NHS White Paper); PRO, MH 55/2094: M. Wilmshurst (Queen`s Institute`s General Superintendent) to Ministry of Health, 19 June 1944, on arrangements for consultations on plans for district nursing in the NHS.

${ }^{37}$ Minutes of evidence to the Joint Committee on the Public Healtr. Bill 1936 (published Parliamentary papers). 
nothing to encourage local authorities to take up the powers, and little use was made of them. ${ }^{38}$ District nursing's marginality to health policy was further confirmed when it was given no place in the wartime Emergency Medical Service. ${ }^{39}$ Policy-makers were benevolently disposed towards district nursing and willing to smooth its path, but saw no need for initiatives that would ensure a complete service until the National Health Service supervened.

The Survey prompted two meetings at the Ministry of Health: an informal visit by members of the Queen's Institute in connection with a pre-publication draft, and a formal deputation after the Survey was published. ${ }^{40}$ The desirability of local authorities having statutory powers as set out in the amended version of Sir Gerald Hurst's Bill of 1934 was not in dispute. A suitable clause was slipped in at the Committee stage of the massive Public Health Bill that was enacted some months later, despite doubts about the constitutional propriety of this convenient procedure. ${ }^{41}$ The Ministry had no occasion to challenge the Survey's estimates of need, but they were vulnerable to criticism on grounds that were quickly identified by the civil servants who scrutinized them. First, and crucially, the basic formula was questioned. The Survey offered no rationale for it other than associations' practical experience, and the civil servants knew of more generous formulae used in recent North American studies and by a major insurance company. One of them produced an estimate of needs for more nurses that was startlingly higher than that in the Survey. ${ }^{42}$

On the other hand, there were objections that the Survey's lack of attention to local variables meant that some needs were overstated. The estimates took no account of the direct employment of nurses by local authorities for the services within their powers, nor of the hospitals that may have reduced the need for home nursing in some of the urban areas that were reportedly most short of nurses. ${ }^{43}$ Such secondary objections did not offset the primary criticisms; the argument was essentially that any basic measure needed much more refinement than was allowed for in the Survey. The civil servants did not comment on its adjustments for factors affecting the size of case-loads, something on which practical experience was likely to have been a sound guide. The formula reflected the current state of affairs without any critical appreciation of other concepts for quantifying the need for more nurses. Even if the urban needs were overstated by the Institute's own standards, they may still have been understated by reference to other criteria.

The Institute was not called upon to defend the methods used in the Survey. The civil servants' statistical exercises were no more than jeux d'esprit, but they were enough to

\footnotetext{
${ }^{38}$ Eleanor Jeanette Merry and Iras Dundas Irven, District nursing, London, Baillière, Tindall and Cox, 1938, p. 31 .

39) Fox, op. cit., note 18 above, pp. 314-18.

4) PRO, MH 55/759, op. cit., notes 28 and 30 above: notes of meetings on 9 July and 20 November 1935.

4 I PRO, HLG 29/227, op. cit, note 31 above, Ministry of Health's departmental advice on a proposed clause for new powers of support. It was a "very large extension" covering what had been suggested in a Bill defeated in the previous Parliamentary session (Z. L. Puxley, Maternal and Child Welfare Division, 29 February 1936); it was a substantial extension of Public Health law and outside the scope of the Bill ("comments by Division III", 13 March 1936). The objection was that the Bill was a consolidating measure, rationalizing existing law but not a vehicle for extending it.

42 PRO, MH 55/759, op. cit., notes 28 and 30 above, departmental comments on the Survey and appended papers, 14 November 1935. The alternative calculation gave an estimate of 14,220 district nurses as Great Britain's minimum requirements for a full service.

${ }^{43}$ Ibid., notes on receipt of the Survey.
} 


\section{District nursing in England and Wales}

indicate not only where the estimates were open to criticism, but also that the civilized accord of the meetings at the Ministry did not mean that the officials deferred unquestioningly to the Institute as the ultimate authority on district nursing, or were likely to do so should the service ever become a political issue of any importance.

The Ministry's records of its officials' reception of the Survey are as good a demonstration as any that its assessment of the needs of given populations did not share the reliability of its measures of territorial coverage. The Ministry, however, took no interest in the part of the Survey that addressed district nursing's current finance, and the official records express no opinion on it.

\section{THE SURVEY: DISTRICT NURSING ASSOCIATIONS' FINANCES}

The Survey includes evidence on associations' income, expenditure, deficits, and the average costs of different types of nurses. The data are presented by reference to 46 counties, defined geographically rather than administratively, and without distinguishing county boroughs. The difference between the 46 and the total of English and Welsh administrative counties used for the other tables is due partly to a lack of data on some of them, and partly to the incorporation of others into larger geographical counties. The data for Essex and the West Riding of Yorkshire are noted only for associations with Queen's nurses.

The information is incomplete, but acceptable on some counts, although the absence of analysis by types of associations is a handicap. For example, the undifferentiated data on associations in credit or deficit on a year's working (deficits for 813 out of 2,909) are of limited utility in that they range over everything from small rural parishes to the biggest urban establishments. The Survey's data are likely to be reasonably reliable on nurses' average costs, and on the general composition of associations' income, even though the absolute totals are understated. The average annual costs per nurse worked out at $£ 207$ for a Queen's nurse working from a superintended Nurses' Home; $£ 231$ for a Queen's nurse elsewhere; and $£ 184.10$ s. for a "non-Queen's" nurse. ${ }^{44}$

The Survey's totals of associations' incomes were summarized in the P.E.P. report in the form shown in Table 4. It understates users' contributions-patients' payments and provident subscriptions-at 39 per cent of the associations' incomes. The Survey acknowledged that some associations did not distinguish provident subscriptions from the charitable "voluntary subscriptions and donations" in their accounts. Also, although the Survey did not mention this, users accounted for some of the money that was collected through special efforts, like flag days.

Income from provident schemes was set to rise; the Institute was reporting good results from the promotion of new forms of provident funding that began at about the time the Survey was put in hand. ${ }^{45}$ As the Institute's other line of action was its lobbying for further

\footnotetext{
${ }^{44}$ Queen's Institute of District Nursing, op. cit., note 11 above, p. 6 on costs and p. 4: "In some places a Village Nurse-Midwife is replaced by a hospital-trained but non-Queen's Nurse". See also Fox, op. cit., note 18 above, pp. 224-6. A tendency for village posts to be taken by State Registered Nurses with midwifery certificates was first noted in 1934; they were likely to commnd higher pay than did village nurse-midwives. As there is no estimate of village nurse-midwives" costs, they are presumably included in that for a "non-Queen "s" nurse.

${ }^{45}$ QICM, 28 February 1934, 11 July 1934, 5 December 1934, 27 February 1935, 10 July 1935, 4 March 1936. The Institute seconded a senior member of its professional staff to work as "Provident Organiser" in early 1934, and reported consistent progress on urban provident schemes thereafter.
} 
Table 4

Income of district nursing associations, 1934 (England and Wales)

\begin{tabular}{lrc}
\hline & $£$ & percentage \\
\hline Voluntary subscriptions and donations & 264,538 & 25 \\
Grants & 181,221 & 17 \\
Other non-beneficiary sources & 197,797 & 19 \\
Patients' payments & 162,918 & 15 \\
Provident schemes & 253,193 & 24 \\
& & 100
\end{tabular}

Source: P.E.P., Report on the British health services, London, P.E.P., 1937, p. 177.

support from public funds, Table 4's evidence of income from grants (meaning from local authorities) is of special interest. The aggregate figure suggests that, with extra money coming from new provident schemes, the associations could look to local authorities for enough to bring their services to completion without seriously endangering their voluntarism, even if new grants were tied to commensurate control by local authorities. That is, most of the costs would still be coming from voluntary sources. But the composition of associations' funds in different areas was as uneven as were the estimates of further needs. Some associations were certainly at risk of becoming subservient to local authorities if these contributed enough to complete the services and claimed proportionate control. London was the outstanding case, with only 23 per cent of income identifiably from users, and 36 per cent from grants. The grants were likely to have been primarily for district nurses' school nursing, a notable feature of the London County Council's educational service. ${ }^{46}$ Even if the Survey materially over-estimated London's needs for more nurses at 63 per cent of existing provision, it looked as if public funding would have to cover the biggest part of total costs of an adequate service.

Grants were especially important for rural associations, largely accounting for the successful rural coverage, even though they may have been relatively small. They were principally for midwifery, and, together with the charges that the associations made for their grant-supported midwifery, were critical for the viability of many rural nursing associations. Too much could be made of comparisons based solely on the Survey's data, but they illustrate wide variations in County Councils' payments to the County Nursing Associations, which customarily distributed the money to rural associations. Derbyshire County Council was exceptional in avoiding co-operation with the voluntary sector; ${ }^{47}$ only 6.9 per cent of the associations' income was from grants, and the county needed 31 more nurses. Devonshire needed 21, with grants that were nearly average, at 16.7 per cent. The respective populations were 615,000 and 459,000. The Welsh counties presented examples of the highest proportions of incomes from grants; Pembrokeshire and

\footnotetext{
${ }^{46}$ Queen's Institute of District Nursing, op. cit., note 11 above, p. 23: 47 Queen's nurses were assigned to school clinics in London in 1934; Fox, op. cit., note 18 above, pp. 316-17: London association's finance was reported to have been seriously affected when schoolchildren's evacuation in 1939 led to the closure of school clinics and the withdrawal of grants.

${ }^{47}$ Fox, ibid., pp. 174-6, 231-3.
} 


\section{District nursing in England and Wales}

Radnorshire were at the top of the range for the whole country, with associations receiving more than 40 per cent of their incomes from the County Councils. Pembrokeshire had a population of 87,000 and the association's total income for the year represented $2 \mathrm{~s}$. per head. The comparative figures for Radnorshire were 21,000 and 3s., with a much higher proportion of income from provident schemes than in Pembrokeshire, which needed 4 more nurses. Radnorshire was one of the few places that needed none. Carmarthenshire was next in the "league table", with grants representing 37.8 per cent of total income and needing 10 more nurses for its population of 179,000 .

These illustrations raise two points to do with local authorities' control and the prospects for users' funding. Grants running at the level of the Welsh examples already carried the likelihood of material official control in the interests of public accountability, but as long as the grants were not for the general nursing that was the associations' reason for being, this could be defended against official interference. The Queen's Institute's inspectors' reports show that friction due to County Medical Officers' intervention in associations' affairs was common in Wales, notably in Merionethshire and Pembrokeshire. ${ }^{48}$ Although cordial relationships were reported in Radnorshire- "the best run county in the Principality"-it was not free of problems in the 1930 s. $^{49}$ Given the difficulties in their own counties or nearby, the Welsh county associations may well have preferred the continued restriction of statutory powers to the chance of more money from the County Councils, even though their coverage lagged behind that achieved in the English counties.

The Queen's Institute concurrently solicited more public funding and promoted provident schemes without identifying an inherent conflict between the two approaches. The Survey demonstrated what the Institute had already accepted in its espousal of new forms of provident funding: users' support was critical for district nursing's future in the voluntary sector, and even though the Institute had long since stopped defining district nursing's clientele as the "sick poor", ${ }^{50}$ neither were the users rich. Might they not object to making voluntary contributions to a service subsidized from rates and taxes, and available to non-contributors? The objection did not apply to grants for services other than general nursing, and not aided out of the voluntary payments.

It was in the nature of a generally available voluntary service, widely supported by its users, that the supporter-users might find themselves subsidizing neighbours who were no worse off than themselves, but they might well distinguish between voluntary and involuntary altruism. This hypothesis would be tested only if new powers produced sizeable grants. In pursuing its lines of action in tandem, with no discernable doubts, and in overriding the objections of the rural associations, the Institute's leaders were perhaps

\footnotetext{
${ }^{4 \times}$ PRO, PRO 3()/63/584, Queen`s Institute's inspections of Merioneth County Nursing Association: discord was noted in 1934 and regularly thereafter, with the association effectively losing control by the mid-1940s. PRO 3)/6.3/405, inspections of Pembrokeshire: reports giving the impression of a loss of control similar to that in Merioneth.

4) PRO, PRO 3(0/63/596, inspections of Radnorshire County Nursing Association: difficulties about collaboration on midwifery were reported in 1937, but relations were "cordial" in the "best run county" in 1939 (report by D. E. Edgley, June 1939).

${ }^{51}$ A. F. C. Bourdillon (ed.), Voluntary social services, London, Methuen, 1945, p. 229: in 1922 the Queen`s Institute defined its clientele as "those who are unable to employ a private nurse in their homes". But the Institute continued to enforce its rule that associations must provide nursing without charge in cases of necessity.
} 


\section{Enid Fox}

merely being realistic about the limited prospects for more public funding through discretionary powers. All the same, the hypothesis illustrates the problems of aiming to provide a universally available service, publicly and politically acceptable, from a combination of charges, charity, provident insurance and public funds. Did the success that the Survey demonstrated also mean that voluntary district nursing was reaching its limits?

\section{CONCLUSIONS: THE LIMITS OF VOLUNTARISM}

This paper promised a review of the Survey and an indication of its significance; but having raised the question of voluntary district nursing's limits, it should offer some judgement. The Queen's Institute and the independent researchers of the late 1930s agreed that an adequate service demanded more than could be provided by voluntarism, but its limits were never tested. District nursing continued to expand until 1939, when the totals of Queen's nurses and village nurse-midwives had risen by 12 per cent: 681 more nurses, more than 41 per cent of the Survey's estimate of further needs-although some of the increase should be discounted as arising from the late affiliation of established associations. $^{51}$ Between 1939 and 1942 there was a sharp decline in the work-force represented by the Institute, followed by modest rises in the later years of the war and steeper increases thereafter. The post-war totals distinguish only between the Queen's nurses and the rest, which includes midwives, trainees and others; there were 7,439 in 1947 , the final year for which figures are available, as against 7,204 in $1939 .{ }^{52}$

The increases cannot be interpreted accurately without more information on the composition of the work-force. Most County Councils used nurse-midwives' agency for the midwifery services that they were required to provide under the Midwives Act of 1936, with the result that more rural posts were created and there was a tendency for village nurse-midwives to be supplanted by more highly-qualified nurses. ${ }^{53}$ In broad terms, it appears that the developments to 1947 followed the pattern revealed by the Survey, perpetuating its unevenness. It should be noted, however, that district nursing's continued expansion was handicapped to some extent from 1942, when the Beveridge Report foreshadowed a comprehensive health service, and more seriously from 1944, with public awareness of plans that were to include home nursing provided at no charge. ${ }^{54}$ Even so, development continued until the National Health Service took over; but what might have happened without it?

Counterfactual reasoning suggests two possibilities. The first corresponds to what happened up to 1948: improved provision, but short of a complete service and still uneven. Rather than this being allowed to continue, the stronger possibility is that of increased state support, with unforeseen consequences leading to district nursing's eventual adoption as a public service - but for other reasons than the intrinsic lack of "the depth and reliability of resources and the overall co-ordination and uniformity required to deal effectively with

\footnotetext{
${ }^{51}$ For example, Essex County Nursing Association affiliated in 1936 (PRO, PRO 30/63/111, Queen's Institute's inspector's report, November 1936).

${ }^{52}$ QIAR, 1939 and 1947.

${ }^{53}$ Fox, op. cit., note 16 above, pp. 252-4.

${ }^{54}$ Sir William Beveridge, Social insurance and allied services, Cmd 6404, London, HMSO, 1942; Ministry of Health, op. cit., note 36 above.
} 
social problems" that is commonly adduced in explanations of the statutory takeover of services initiated by voluntary enterprise. ${ }^{55}$ Once the National Health Service was in train, district nursing's wartime and post-war growth continued to obtain relatively little support from public funds, not because it was still "invisible in policy debate", but because it was marking time, expecting soon to be taken over. Had there been no such expectation, the second possibility was in prospect, carrying with it the problems of combining different forms of funding that were outlined in the last section, and which could have become critical.

District nursing had just begun to lose its "invisibility" by the beginning of the war. It was in the terms of reference of an official committee set up in 1937 to review all nursing services and chaired by the Earl of Athlone, who was also Chairman of the Queen's Institute's Council. ${ }^{56}$ The onset of war meant that the committee was disbanded after an interim report that did not cover district nursing, with its chairman despatched to be Canada's Governor-General; there was nothing about district nursing alone to keep it on the political agenda. Had the Athlone Committee completed its work, or had post-war policy proceeded on pre-war lines, the most likely outcome would have been increased grants for district nursing. With no evidence of public demand for a statutory service, and a voluntary sector resistant to losing control and not open to criticism on grounds of unreliability, lack of co-ordination and so on, policy was likely to have aimed at making good the voluntary sector's shortfall by encouragements and inducements for local authorities to make more use of the statutory powers conferred on them in 1936.

Using public funds to fill the gaps in voluntary provision, whether by discretionary powers or through the constrained responsibility proposed by Braithwaite ${ }^{57}$ was not as easy as it looked. As the Survey showed, provident funding accounted for nearly a quarter of district nursing associations' incomes even by 1934, when the promotion of new, large urban schemes was barely under way. Provident funding was district nursing's life-blood, accounting for much of its development from the mid-1930s, and its scope was not exhausted by 1947. But it was the most difficult form of funding to combine with statutory aid, for reasons already outlined. The Queen's Institute's rule was that non-contributors should not be denied attendance, if necessary without charge. Such patients might have been unable to pay anything towards the cost of their nursing, and yet have been no worse off than many members of associations' provident schemes. Nursing poor noncontributors and playing fair by equally poor contributors was a perennial problem for the associations. They customarily contained it, but not without tension..$^{58}$ As suggested earlier, a local authority's decision to aid district nursing might affect provident schemes' membership. People who were already mildly resentful about subsidizing nursing for others no worse off than themselves, yet willing to do so for the sake of maintaining the service, might change their minds on the grounds that if public funds were to be used they should benefit everyone alike.

\footnotetext{
${ }^{55}$ Geoffrey Finlayson, 'A moving frontier: voluntarism and the state in British social policy', Twentieth Century British History, 1990, 2: 183-206, p. 187.

${ }^{56}$ Ministry of Health and Board of Education, Interim report of the interdepartmental committee on nursing services, London, HMSO, 1939.

${ }_{57}$ Braithwaite op. cit., notes 6 and 13 above.

${ }^{58}$ Fox, op. cit., note 18 above, pp. 269-72.
} 
According to this scenario, the result would be a spiralling decline in users' funding and, possibly not without controversy, a corresponding increase in public funding and an eventual transfer of control. Given the increases in district nursing's work-force by 1939 , evenly spread grants to bring it to the Queen's Institute's estimates of adequacy might not have been enough to prompt a users' backlash, but the unevenness evidenced by the Survey suggested that they could have been destabilizing. Once the provision of adequate home nursing was on the political agenda, withdrawals of users' funds were more likely to have been compensated by bigger grants than allowed to result in the service's decline.

There is no point in pursuing the counterfactual argument further, but it demonstrates that even though different publicly provided services may have similar histories of voluntary beginnings, relationships between the voluntary and statutory sectors may not all follow the same pattern, and need to be seen in the context of the particularities of each specific service. The National Health Service was paid for out of central taxation, and its inclusion of district nursing presented no complications over combining different methods of funding. Other problems arose from incorporating a service that had been wholly developed in the voluntary sector with little co-operation from the state; the story has been opened up elsewhere. ${ }^{59}$ There is more to be told, with public records providing basic centralized information that district nursing's earlier history has been said to lack. This paper has demonstrated that the Queen's Institute's quantitative dominance justifies the claim that its records constitute a substantial central archive,${ }^{60}$ but has only been able to do so by citing the hitherto neglected Survey.

It is not here claimed that the Institute stood for all district nursing. There are aspects of independent associations that may have been disproportionately important, and the Institute's system should not be taken as representative even of its affiliates, despite their adherence to its rules. Affiliation ensured a supply of nurses, helped associations to avoid problems inherent in managing professional staff, and was likely to be preferred by the local authorities that used district nurses' agency and valued the standardized practices that it promised. Its functional benefits may have led some associations to opt for it without necessarily agreeing with the Institute on all things. The Institute's use of the Survey shows that it could be autocratic.

But any central archive, public or private, has to be approached with reservations. The Survey indicates something of what they should be, as well as establishing the importance of the Institute's central records. On its own, or in conjunction with the Institute's papers, the Survey is likely to help identify areas where local records may be especially informative on non-affiliated nursing. Its collated information is not the only reason for rescuing it for history; it is an invaluable aid to selecting, assessing and organizing detailed local research on the generally neglected topics of district nursing and the non-institutional health services that foreran the National Health Service. District nursing may be a humdrum preoccupation for the medical historian-certainly much less compelling than,

\footnotetext{
${ }^{59}$ Ibid., pp. 312-43; Baly, op. cit., note 8 above, pp. 101-20.

(6) The Queen's Institute's records are currently held at three locations: the offices of the Queen's Nursing Institute, London; the Contemporary Medical Archives Centre, Wellcome Institute for the History of Medicine, London; and the Public Record Office, Kew. The PRO collection is a selection of papers on the Institute's dealings with its affiliates.
} 


\section{District nursing in England and Wales}

say, madness, sexuality, or addiction-but its history has much to offer the student of health care, professionalization, and voluntarism. The heavy stress on primary and community care in the health and social policies of the 1990s adds to its interest, as does the current and projected age structure of the population. The people to whom voluntary district nursing was uniquely valuable were the old and chronically sick; and even medical historians grow old. 